\title{
Deep Vein Thrombosis Complicating SS Sickle Cell anemia in Pregnancy: About a Case Diagnosed at the Issaka Gazobi Maternity
}

\author{
Chaibou-Yacouba Maimouna1*, Hamidou Soumana-Diaouga1, Amadou Djibrilla-Almoustapha',3, \\ Moctar Abdoulaye-Maliki', Mansour Sidi-Mahamane², Madeleine Garba-Rah",2, Idi Nafiou ${ }^{2,3}$, \\ Madi Nayama ${ }^{1,2}$ \\ ${ }^{1}$ Issaka Gazobi Maternity, Niamey, Niger \\ ${ }^{2}$ Science of Health Faculty, Abdou Moumouni University of Niamey, Niamey, Niger \\ ${ }^{3}$ Hematology Department of the Niamey National Hospital, Niamey, Niger \\ ${ }^{4}$ Cardiology Department of the Niamey National Hospital, Niamey, Niger \\ Email: ${ }^{\star j u l i e c h a i b o u y a c o u b a @ g m a i l . c o m ~}$
}

How to cite this paper: Maimouna, C.-Y., Soumana-Diaouga, H., Djibrilla-Almoustapha, A., Abdoulaye-Maliki, M., Sidi-Mahamane, M., Garba-Rah, M., Nafiou, I. and Nayama, M. (2021) Deep Vein Thrombosis Complicating SS Sickle Cell anemia in Pregnancy: About a Case Diagnosed at the Issaka Gazobi Maternity. Open Journal of Blood Diseases, 11, 25-30.

https://doi.org/10.4236/ojbd.2021.112004

Received: February 23, 2021

Accepted: April 5, 2021

Published: April 8, 2021

Copyright (c) 2021 by author(s) and Scientific Research Publishing Inc. This work is licensed under the Creative Commons Attribution International License (CC BY 4.0).

http://creativecommons.org/licenses/by/4.0/ (c) (i) Open Access

\begin{abstract}
Pregnancy in a sickle cell patient is a source of maternal and perinatal morbidities. Thromboembolic diseases of which Deep Vein Thrombosis (DVT) is one of the complications. The frequency of the latter is poorly assessed. Very few studies have been done on this topic. We report a case of DVT in a 35year-old patient with sickle cell SS pregnant with 27SA diagnosed and cared for at the Maternity Issaka Gazobi (MIG) in Niamey. The management was based on low molecular weight heparin combined with preventive measures against sickle cell anemia and a planned cesarean section which led to a favorable maternal and perinatal prognosis.
\end{abstract}

\section{Keywords}

DVT, Sickle Cell Disease, Gravido-Puerperalitis, MIG, Niamey

\section{Introduction}

Deep vein thrombosis defines the presence of a thrombus in a deep vein and the accompanying inflammatory response of the vascular walls [1]. Deep Vein Thrombosis (DVT) is one of the components of Veno-Thrombo-Embolism (VTE), the most common complication of pregnancy, occurs in antenatal and/or postpartum [2]. This question remains a major concern in the management of women with sickle cell disease during pregnancy and childbirth [3]. Many deaths in pregnant women with sickle cell disease are attributable to thromboembolic events, yet 
the overall risk in these women has never been fully explored [4]. We report a case of DVT of the right leg of a 35-year-old patient with SS sickle cell disease with a pregnancy of 27 weeks at the Issaka Gazobi maternity in Niamey.

\section{Observation}

35 year old patient aged, six gestities, three previous parities, zero living children, two deceased, three abortions (G6P3V0D2A3), pregnant with 27 weeks, sickle cell disease SS ( $\mathrm{HbS}=95.3 \%$ and $\mathrm{A} 2=4.7 \%)$ not well known followed. There is several history of hospitalizations and transfusions for her hemoglobin disease, she was admitted to the obstetric department of the MIG for osteoarticular vaso-occlusive crises (OVC). On examination, the patient was conscious (Glasgow: 15/15), anxious, the conjunctivities and mucous membranes were moderately colored, diffuse bone pain (VAS: 7/10), blood pressure (BP) was 110/ $70 \mathrm{mmHg}$, pulse at 112 beats $/ \mathrm{min}$ and temperature $\left(\mathrm{T}^{\circ}\right)$ at $37^{\circ} \mathrm{C}$, Height $=1$ $\mathrm{m} 68$, Weight $=58 \mathrm{~kg}, \mathrm{BMI}=20.54 \mathrm{~kg} / \mathrm{m}^{2}$. Painful swelling of the entire right leg with total functional impairment of the pelvic limb, reduced calf sloshing and a positive Homans sign. The clinical probability according to the Wells score was high ( 3 points). The obstetric examination was normal, the fetal heart sounds were at 120 beats/min. A Doppler ultrasound of the right pelvic limb was requested and demonstrated extensive venous thrombosis of the tibio-peroneal trunk (Figure 1). The Full Blood Count (FBC) revealed severe microcytic anemia (Hb: $6.4 \mathrm{~g} / \mathrm{dl}$ ), Mean Blood Volume (MBV: $76 \mathrm{fl}$ ), normal platelet count (Plq: $135,000 / \mathrm{mm}^{3}$ ) and C reactive protein (CRP) at $5 \mathrm{mg} / \mathrm{l}$. D-Dimers have not been requested. Taking into account the clinical data and the obstetric examination, the sickle cell site and the Doppler ultrasound data of the limbs, the diagnosis is that of a venous thrombosis of the tibio-peroneal trunk of the right leg

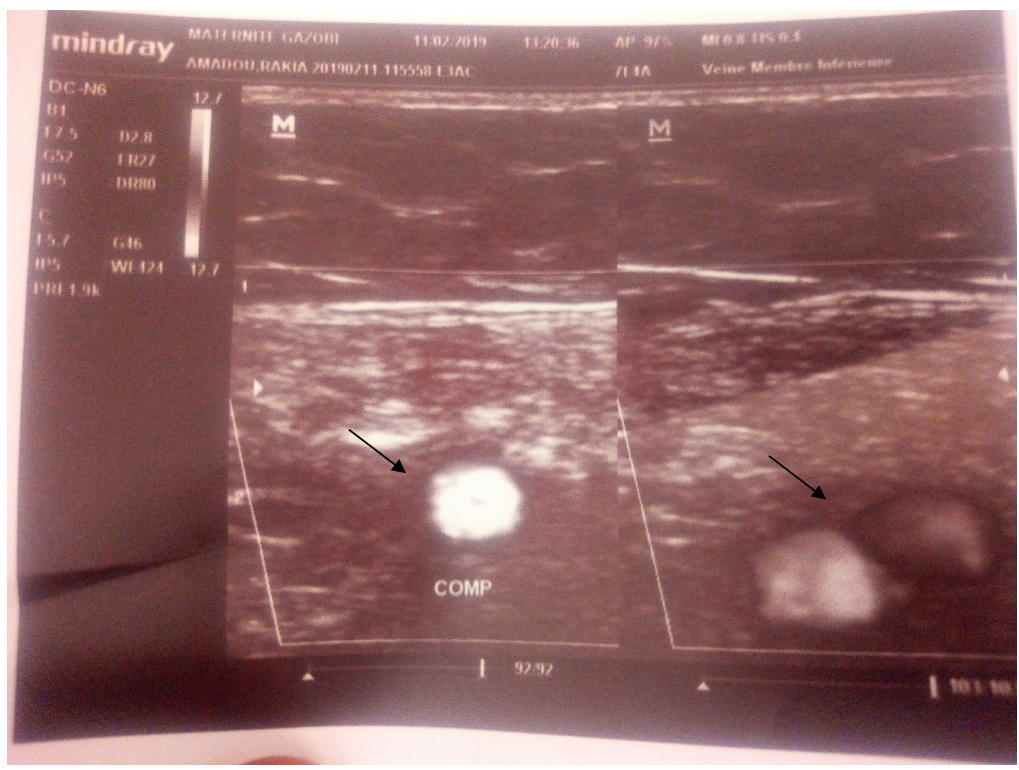

Figure 1. Ultrasound image showing a thrombus of the tibioperonier trunk and incompressible vein. 
on sickle cell site SS pregnant with 27 weeks, deglobulized. She was hospitalized in the intensive care unit where she received treatment with enoxaparin 100 $\mathrm{UI} / \mathrm{kg}$ every 12 hours until delivery, an elastic compression stocking, treatment for OVC and a transfusion program until she had an $\mathrm{HbS}$ level of $31 \%$ with phenotyped red blood cells. The outcome was favorable and a caesarean section has been programmed at 35 WA which resulted in the birth of a live female newborn with an Apgar score of 10 at the 5th minute, a birth weight of $1800 \mathrm{~g}$. The postoperative follow-up was straightforward with discharge authorized after 7 days postoperatively.

\section{Discussion}

Pregnancy is a factor favoring the onset of thrombosis by increasing the risk of developing VTE by 4 to 5 times and by up to $80 \%$ for DVT and $20 \%$ for PE. The absolute risk of VTE during pregnancy is between $0.5 \%$ and $2.0 \%$ per 1000 deliveries. During the postpartum period, the risk increased 20 to 80 times in the first 6 weeks after childbirth [5]. This risk is amplified in pregnant women with sickle cell anemia, which is also in itself a factor in the occurrence of thrombosis, the mechanism of which remains uncertain [6].

Sickle cell disease is the most common genotypic disorder in the world and especially with migratory flows [7]. It is due to a single mutation in the $\beta$-globin gene responsible for the synthesis of abnormal hemoglobin $S$ that causes clinical manifestations. VTE was only relatively recently recognized as a frequent complication of this pathology and was possibly underestimated previously [8]. Our patient is sickle cell major SS, pregnant with 27 weeks with DVT. There are very few studies on the frequency of occurrence of VTE in pregnant women with sickle cell disease in Africa and Niger; some local studies carried out on DVT in pregnant women with sickle cell disease reported a maternal morbidity rate of $1.6 \%[9]$.

According to data from the literature, some authors, by examining the relationship between major sickle cell syndromes and the risk of VTE during the pregnancy-puerperium, found that $2.9 \%$ of SS women presented with VTE [10]. Others have reported 1.5 to 5 times more VTE than in the general pregnancy population [5]. So these data suggest that the risk of VTE during pregnancy increases especially with sickle cell anemia and the postpartum constitutes a high risk period. In our patient in addition to DVT, complications like OVC and severe anemia were found. In fact, OVC, Acute Chest Syndrome (ACS) and anemia in the group of sickle cell women with VTE dominated compared to the sickle cell population without VTE in the literature data. These findings suggest that there is a frequent association of VTE with other complications of sickle cell disease, so rigorous monitoring is the rule in this group of patients. The diagnosis of DVT is clinical and paraclinical. However, during pregnancy, the classic picture is changed. In fact, the classic risk factors for DVT of the lower limbs are rarely present during pregnancy, which complicates the determination of the 
pre-test clinical probability. The signs and symptoms of the disease (edema, pain, heaviness, and erythema) are unspecific and very common in pregnant women. However, during pregnancy, three elements must be taken into account to establish the clinical probability of DVT: involvement of the left lower limb, an asymmetry of calf perimeter of more than $2 \mathrm{~cm}$ and the onset of symptoms during the first trimester of pregnancy [11]. In our patient the diagnosis was suspected in front of a large painful right leg. The presence of at least one of these three criteria was associated with a prevalence of thrombosis of $16 \%$ and this prevalence reached 58\% when at least two items were present [11] [12]. In our patient, the swelling was localized to the right and only one of the 3 criteria was found, namely swelling of the leg, which is also a possibility.

The key diagnostic examinations were D. dimeres and Doppler ultrasound. However during pregnancy there is a physiological increase in D. dimers; the impliRED test which is a D. dimeres test appears to be sensitive and specific enough to be clinically useful in pregnant women suspected of having DVT. The usefulness of this test is high for at least the first 2 trimesters of pregnancy [13]. In our case, we did not find it useful to request this test because in the third trimester of pregnancy.

Doppler ultrasound has been the gold standard in our setting. Indeed very sensitive and specific in the diagnosis of proximal venous thrombosis but less specific in the diagnosis of distal venous thrombosis and pelvic venous thrombosis [14].

It was a source of diagnostic confirmation in our patient. The management included a treatment based on strong rehydration, analgesic and antibiotic. Several studies confirm that management based on certain preventive measures, such as rewarming, oxygenation, optimal hydration of the sickle cell patient and an adequate transfusion program made it possible to limit the risk of maternal and perinatal complications [15] [16].

Enoxaparin at $100 \mathrm{IU} / \mathrm{kg}$ every 12 hours was the treatment of choice used to treat DVT associated with a compression stocking in our patient. Indeed during pregnancy the therapeutic choice is very limited; direct oral anticoagulants (anti-X or anti-II) are contraindicated because they cross the blood-placental barrier, antivitamins $\mathrm{K}$ used in the 3rd trimester expose a high risk of bleeding during delivery and are difficult to handle in pregnant women by against authorized postpartum [17].

Thus only heparins, in particular low molecular weight heparins (LMWH) are used during this period, they have the advantage of not requiring clinical monitoring in practice and of being easy to use [11].

In our observation, the mode of delivery was a cesarean section scheduled at 35 weeks as a precaution in view of our patient's heavy obstetric history and a therapeutic window of 2 days was performed to limit the risk of bleeding. The operative consequences were simple for our patient. The management of women with sickle cell disease must also be based on genetic counseling. Low-dose aspirin $100 \mathrm{mg} /$ day, which is currently not systematic but prescribed in case of add- 
ed factors of pre-eclampsia. The broad prescription of elastic restraint of the lower limbs throughout pregnancy and post-partum, associated with antenatal thromboprophylaxis by LMWH, will be carried out in the event of added risk factors for VTE [8] [16].

\section{Conclusion}

The combination of sickle cell anemia and pregnancy is a high risk situation for the mother and her fetus. This situation is the source of many maternal complications, including thrombosis, which is responsible for many maternal deaths. It requires better knowledge, supported by diagnostic means for adequate treatment based on prevention.

\section{Authors Contribution}

Chaibou-Yacouba Maimouna was largely contributed to the realization of this work, passing by the diagnosis of the therapeutic decision ant the writing of the work.

Madi Nayama contributed to the patient but also the development of the body of this work.

\section{Conflicts of Interest}

The authors declare no conflicts of interest regarding the publication of this paper.

The informed consent of the patient has been requested.

\section{References}

[1] Baurain, J.F. (2013) Prévention et traitement des thromboembolies veineuses. Réunion de consensus INAMI 21 novembre 2013.

[2] Magali, S. (2007) Suivi des grossesses et des accouchements des patientes sous traitement anticoagulant à la maternité régionale A. Pinard de Nancy. Sciences du Vivant [q-bio]. hal-01732600

[3] Noubouossie, D. and Key, N.S. (2015) Sickle Cell Disease and Venous Thromboembolism in Pregnancy and the Puerperium. Thrombosis Research, 135, S46S48. https://doi.org/10.1016/S0049-3848(15)50442-8

[4] Villers, M.S., Jamison, M.G., Castro, L.M.D. and James, A.H. (2008) Morbidity Associated with Sickle Cell Disease in Pregnancy. American Journal of Obstetrics \& Gynecology, 199, 125E1-125.E5. https://doi.org/10.1016/j.ajog.2008.04.016

[5] Seaman, C.D., Yabes, J., Li, J., Moore, C.G. and Ragni, M.V. (2014) Venous Thromboembolism in Pregnant Women with Sickle Cell Disease: A Retrospective Database Analysis. Thrombosis Research, 134, 1249-1252. https://doi.org/10.1016/j.thromres.2014.09.037

[6] Shet, A.S. and Wun, T. (2018) How I Diagnose and Treat Venous Thromboembolism in Sickle Cell Disease. Blood, 132, Article No. 1761. https://doi.org/10.1182/blood-2018-03-822593

[7] Coumba, S. (2004) Enquête sur les connaissances et attitudes des mères face à la prise en charge des enfants drépanocytaires dans les ménages à Bamako [Thèse de 
doctorat en médecine]. Université de Bamako, Bamako.

[8] Lecouffe-Desprets, M., Graveleau, J., Artifoni, M., et al. (2019) Maladies hémolytiques et thrombose veineuse: Mise au point. La Revue de Médecine Interne, 40, 232 237. https://doi.org/10.1016/j.revmed.2018.10.387

[9] Sahabi, A. (2017) Drépanocytose et grossesse à la maternité Issaka Gazobi [Mémoire en Médecine, Gynécologie obstétrique]. Université Abdou Moumouni de Niamey, Niamey.

[10] Porter, B., Key, N.S., Jauk, V.C., Adam, S., Biggio, J. and Tita, A. (2014) Impact of Sickle Hemoglobinopathies on Pregnancy-Related Venous Thromboembolism. American Journal of Perinatology, 31, 805-810. https://doi.org/10.1055/s-0033-1361931

[11] Delluc, A. (2016) Prise en charge de la maladie thromboembolique au cours de la grossesse. Vocation de Sage-Femme, 15, 15-18. https://doi.org/10.1016/j.vsf.2016.01.004

[12] Barfield, W.D., Barradas, D.T., Manning, S.E., Kotelchuck, M. and Shapiro-Mendoza, C.K. (2010) Sickle Cell Disease and Pregnancy Outcomes. American Journal of Preventive Medicine, 38, S542-S549. https://doi.org/10.1016/j.amepre.2009.12.020

[13] Torkzad, M.R., Bremme, K., Hellgren, M., Eriksson, M.J., Hagman, A., Jörgensen, T., et al. (2010) Magnetic Resonance Imaging and Ultrasonography in Diagnosis of Pelvic Vein Thrombosis Durind Pregnancy. Thrombosis Research, 126, 107-112. https://doi.org/10.1016/j.thromres.2010.05.011

[14] Horellou, M.H., Plu-Bureau, G. and Lepercq, J. (2014) Maladie Thromboembolique veineuse et grossesse. La Revue De Medecine Interne, 10, 356

[15] Habibi, A., Arlet, J.B., Stankovic, K., Gellen-Dautremer, J., Ribeil, J.-A., Bartolucci, P., et al. (2015) Recommandations françaises de prise en charge de la drépanocytose de l'adulte: Actualisation 2015. La Revue de Médecine Interne, 36, S83-S84. https://doi.org/10.1016/S0248-8663(15)60002-9

[16] Société Française d'Anesthésie et de Réanimation (2005) RPC Prévention de la maladie thromboembolique veineuse périopératoire et obstétricale. http://www.sfar.org

[17] Camous, J., N’da, A., Etienne-Julan, M. and Stéphan, F. (2008) Anesthetic Management of Pregnant Women with Sickle Cell Disease: Effect on Postnatal Sickling Complications. Canadian Journal of Anesthesia, 55, 276-283.

https://doi.org/10.1007/BF03017204 